\title{
Survey of Entomopathogenic Organisms of the Cantharis livida Linnaeus, 1758 (Coleoptera: Cantharidae) in Turkey
}

\author{
Çağrı BEKİRCAN ${ }^{1}$, Onur TOSUN ${ }^{* 2}$, Hilal YILDIRIM ${ }^{3}$ \\ ORCID: 0000-0002-5968-7359; 0000-0002-6763-5671; 0000-0002-6072-5543
}

\author{
${ }^{1}$ Turkey Selçuk University, Sarayönü Vocational School, Department of Veterinary Medicine Konya, Turkey \\ ${ }^{2}$ Karadeniz Technical University, Maçka Vocational School, Department of Veterinary Medicine, Trabzon, Turkey \\ ${ }^{3}$ Giresun University, Espiye Vocational School, Department of Plant and Animal Production, Giresun, Turkey
}

\begin{abstract}
In the present study, one cephaline (septate) gregarine and mermithid infections were reported from the Cantharidae family for the first time. These infections were determined from different populations of Cantharis livida L. 1758 (Coleoptera: Cantharidae) in Turkey. During the observations, the main life stages of the current gregarine like trophozoite, gamont associative form (syzygy) and gametocyst stages were observed. The gamont stage which separated into two parts by septum as protomerite and deutomerite was the most common stage in the host gut and ovocylindrical gamonts measured $240.4 \pm 29.0(154.5-306.2 ; n=40) \mu \mathrm{m}$ in length. The mermithid infection was observed only in two samples which were collected from Rize (total infection rate 3.22\%). The determined juvenile forms were measured $270-281 \mu \mathrm{m}$ in width and 68.6-79.98 $\mathrm{mm}$ in length.
\end{abstract}

Keywords: Cantharidae, Cantharis livida, Coleoptera, gregarine, mermithid

\section{Cantharis livida Linnaeus, 1758 (Coleoptera: Cantharidae)'nın entomopatojenik organizmalarının araştırılması}

\section{Özet}

Bu çalışmada Cantharidae familyasında ilk kez enfeksiyon yapan bir gregarin ve mermitid enfeksiyonu tespit edilmiştir. Bu enfeksiyonlar Türkiye'deki farklı Cantharis livida L. 1758 (Coleoptera: Cantharidae) popülasyonlarından belirlenmiştir. Araştırma sırasında gregarine patojenine ait ana yaşam evreleri (Trofozoit, Gamont, sizigi ve gametosit) gözlendi. Septum yapısı ile protomerit ve deutomerit olarak iki kısma ayrılan Gamont aşaması konak bağırsağında en sık rastlanan aşamadır ve 240,4 $\pm 29,0(154,5-306,2 ; n=40) \mu$ m boyutlarında ölçülmüştür. Mermitid enfeksiyonu sadece Rize ilindeki popülasyonda iki örnekte gözlenmiştir (toplam enfeksiyon oranı \% 3,22). tespit edilen juvenil formları 270-281 $\mu \mathrm{m}$ genişliğinde ve 68,6-79,98 mm uzunluğunda ölçülmüştür.

Anahtar kelimeler: Cantharidae, Cantharis livida, Coleoptera, gregarine, mermithid

\section{Introduction}

The soldier beetles (Coleoptera: Cantharidae) contain important predator species that prey upon a variety of aphids, whiteflies, lepidopteran eggs, thrips, and mites [1]. With these features, these beetles have great potential to use in biological control of the different pests. These beetles have pubescent soft-body and are characterized by the shape of the metasternal-metepisternal suture. This cosmopolitan taxon shows the presence in Turkey with the many species belonging to the Cantharis and Malthodes genera [2]. Cantharis livida Linnaeus, 1758 (Coleoptera: Cantharidae) is a

\footnotetext{
${ }^{*}$ Corresponding author / Haberleşmeden sorumlu yazar: Tel.: +905417661961; Fax.: +904625123552; E-mail: onrtsn61@ hotmail.com

(c) Copyright 2020 by Biological Diversity and Conservation $\quad$ Received: 13.04.2020; $\quad$ Published: 15.12.2020 BioDiCon. 908-0420
} 
predator especially insect pests of poplar species in Turkey [3]. The predatory insects like a C. livida play a significant role in agricultural and environmentally sustainable pest control systems. Therefore, for successful biological control, we need to know knowledge that relies on their natural pathogen and enemies in addition to basic biological information on these type of predatory insects.

With the adoption of biological control techniques as a new approach to chemical control, entomopathogenic organisms emerged as promising factors [4]. Although entomopathogenic organisms are useful factors in the fight against pests, these friendly organisms may appear as unwanted enemies when it comes to beneficial insects. Therefore, great efforts have been spent on the isolation and identification of these organisms, all over the world especially the last couple of decades $[5 ; 6 ; 7]$. There is a lot of researches for determined the entomopathogens of the Cantharidae family $[8 ; 9 ; 10 ; 11 ; 12]$.There is no record of entomopathogenic organisms infecting C. livida.

In this study, two entomopathogenic organisms; a gregarine and a nematode from $C$. livida populations were reported for the first time.

\section{Materials and Methods}

C. livida individuals were collected from April to August 2018-2019 at different localities in Rize and Giresun province of Turkey. The insect samples were placed in separate plastic boxes and transported laboratory as soon as possible. The thorax and abdomen internal organs of each specimen were excised and examined for natural pathogens and parasites of $C$. livida by light microscope [13; 14]. Samples were examined under a light microscope at a different magnification from $100 \mathrm{X}$ to $1000 \mathrm{X}$. Isolated parasites were photographed with a Zeiss AXIO microscope with an Axicam ERc5s digital camera. The measurements were taken using ZEN 2.3 Blue Edition imaging software. Morphological characters and necessary measurements that are important for the systematic of gregarine and mermithid parasites were determined as in the literature $[15 ; 16]$.

\section{Results}

During the 2018 and 2019, 62 adult $C$. livida members were collected from different populations. Result of the microscopical observations, two different entomopathogens; a gregarine (Apicomplexa: Eugregarinorida), and one nematode (Nematoda: Mermithida) were determined in the populations of C. livida. The first one was a gregarine and this pathogen was determined from all populations of the C. livida from Rize and Giresun and the total infection rate was determined as $9.6 \%$. During the observations, main life stages like trophozoite, gamont associative form (syzygy) and gametocyst stages were observed (Figure 1). Trophozoites with cube-shaped epimerite at the apical tip were determined as globular or oval in shaped in the host gut (Figure 1A). Gamonts which separated into two parts by septum as protomerite and deutomerite were the most common stage in the host gut (Figure 1B). Ovocylindrical gamonts measured $240.4 \mu \mathrm{m} \pm 29.0 \mu \mathrm{m}(154.5-306.2 \mu \mathrm{m} ; \mathrm{n}=40) \mu \mathrm{m}$ in length in the host gut. The protomerites were mostly oval shape and measured $43.9 \mu \mathrm{m} \pm 5.4 \mu \mathrm{m}(34.3-60.1 \mu \mathrm{m} ; \mathrm{n}=40)$ in length and 50.1 $\mu \mathrm{m} \pm 7.1 \mu \mathrm{m}(30.3-68.7 \mu \mathrm{m} ; \mathrm{n}=40) \mu \mathrm{m}$ in width. On the other hands, cylindrical deutomerites was measured as a $196.5 \mu \mathrm{m} \pm 26.4 \mu \mathrm{m}(120.2-246.1 \mu \mathrm{m} ; \mathrm{n}=40)$ in length and $77.6 \mu \mathrm{m} \pm 10.6 \mu \mathrm{m}(51.5-97.2 \mu \mathrm{m} ; \mathrm{n}=40)$ in width (Table 1). The associative forms (syzygy) which were consist of primite and satellite, were detected in the host gut (Figure 1C). The primite and satellite structures were measured as $236.8 \mu \mathrm{m} \pm 8.6 \mu \mathrm{m}(217.5-248.9 \mu \mathrm{m} ; \mathrm{n}=10)$ and $241.9 \mu \mathrm{m} \pm 17.7 \mu \mathrm{m}(214.6-263.3 \mu \mathrm{m} ; \mathrm{n}=10)$, respectively. Also, the length of protomerite (LP), the length of deutomerite, the wide of protomerite (WP) and deutomerite (WD) and etc. which belonging to structures of primite and satellite were measured and recorded (Table 1). The last observed stage was the gametocyst stage and this spherical stage measured as $262.1 \times 276.2 \mu \mathrm{m}$ in diameter in the host gut (Figure 1D).

The second entomopathogenic organism determined from $C$. livida members was a nematode. This entomopathogenic nematode observed only in two samples which were collected from Rize (total infection rate $3.22 \%$ ). The observed nematode was a member of the family Mermithidae with wire-like body shape and smooth cuticle with layers of spiral fibres. During the examination, only juvenile stages were determined and these juveniles had a blunt apical end with characteristic evident straight-rounded tail appendage with $51.8 \mu \mathrm{m}$ length (Figure $2 \mathrm{~A}, \mathrm{~B}$ ). According to measurements, the samples measured $270-281 \mu \mathrm{m}$ in width and $68.6-79.98 \mathrm{~mm}$ in length. 


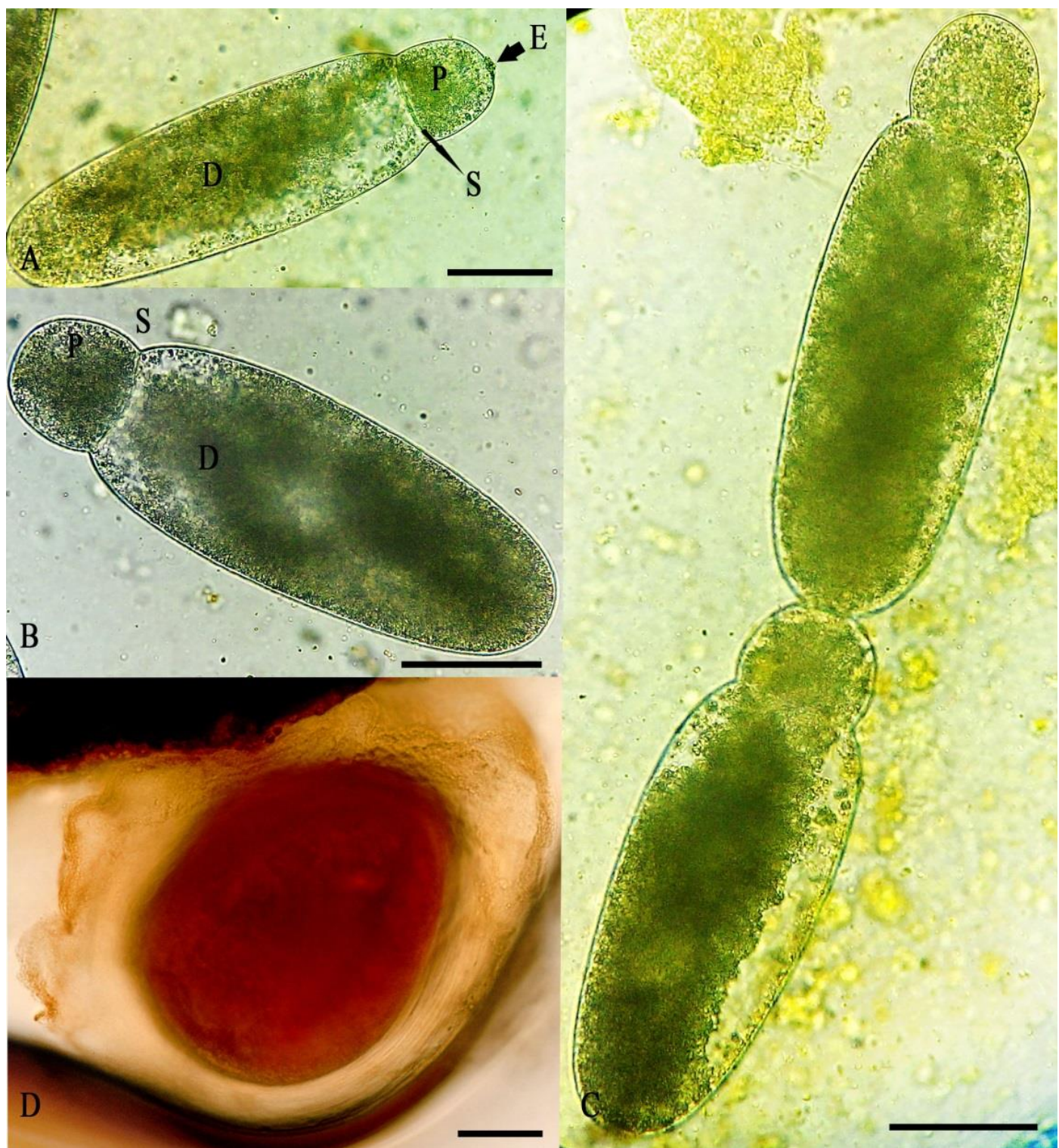

Figure 1. Life stages of the current cephaline (septate) gregarine from C. livida; Trophozoite (A), gamont (B), associative form (C) and gametocyst (D) of the gregarine. Abbreviations: E: epimerite, S: septum, D: deutomerite, P: protomerite, (Bars: $50 \mu \mathrm{m})$

Table 1. The measurements of gamont and associative forms (syzygy) stages of the current gregarine (in $\mu \mathrm{m}$ )

\begin{tabular}{|c|c|c|c|c|c|c|c|c|}
\hline & & $\mathrm{TL}$ & LP & $\mathrm{LD}$ & WP & WD & LP:TL & WP: WD \\
\hline $\begin{array}{l}\text { Gamor } \\
\text { (n: } 40\end{array}$ & & $\begin{array}{c}240.4 \pm 29.0 \\
(154.5-306.2)\end{array}$ & $\begin{array}{c}43.9 \pm 5.4 \\
(34.3-60.1)\end{array}$ & $\begin{array}{c}196.5 \pm 26.4 \\
(120.2- \\
246.1)\end{array}$ & $\begin{array}{c}50.1 \pm 7.1 \\
(30.3- \\
68.7)\end{array}$ & $\begin{array}{l}77.6 \pm 10.6 \\
(51.5-97.2)\end{array}$ & $\begin{array}{l}5.5 \pm 0.7 \\
(4.3-7.4)\end{array}$ & $\begin{array}{l}1.6 \pm 0.1 \\
(1.1-1.8)\end{array}$ \\
\hline & & TL & LP & LD & WP & WD & LP:TL & WP: WD \\
\hline . & $\begin{array}{l}\text { Primite } \\
\text { (n: 10) }\end{array}$ & $\begin{array}{c}236.8 \pm 8.6 \\
(217.5-248.9)\end{array}$ & $\begin{array}{c}43.5 \pm 4.9 \\
(37.2-51.6)\end{array}$ & $\begin{array}{c}193.3 \pm 10.8 \\
(171.7- \\
206.1)\end{array}$ & $\begin{array}{c}47.4 \pm 5.9 \\
(37.2- \\
56.1) \\
\end{array}$ & $\begin{array}{c}65.3 \pm 8.6 \\
(52.6-81.3)\end{array}$ & $\begin{array}{c}5.5 \pm 0.7 \\
(4.6-6.5)\end{array}$ & $\begin{array}{c}1.4 \pm 0.2 \\
(1.1-1.6)\end{array}$ \\
\hline 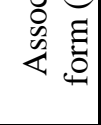 & $\begin{array}{l}\text { Satellite } \\
\text { (n: 10) }\end{array}$ & $\begin{array}{c}241.9 \pm 17.7 \\
(214.6-263.3)\end{array}$ & $\begin{array}{c}47.1 \pm 6.4 \\
(40.1-52.1)\end{array}$ & $\begin{array}{c}194.9 \pm 14.2 \\
(174.5- \\
211.8)\end{array}$ & $\begin{array}{c}54.5 \pm 6.8 \\
(42.9- \\
60.7)\end{array}$ & $\begin{array}{c}68.1 \pm 13.8 \\
(57.2-85.8)\end{array}$ & $\begin{array}{c}5.2 \pm 0.6 \\
(4.6-6.1)\end{array}$ & $\begin{array}{c}1.3 \pm 0.3 \\
(0.9-1.5)\end{array}$ \\
\hline
\end{tabular}

a; minimal and maximal, TL; total length, LP; length of protomerite, LD; length of deutomerite, WP; width of protomerite, WD; width of deutomerite, LP:TL; ratio of the length of protomerite to total length, WP:WD; ratio of the width of protomerite to the width of deutomerite. 


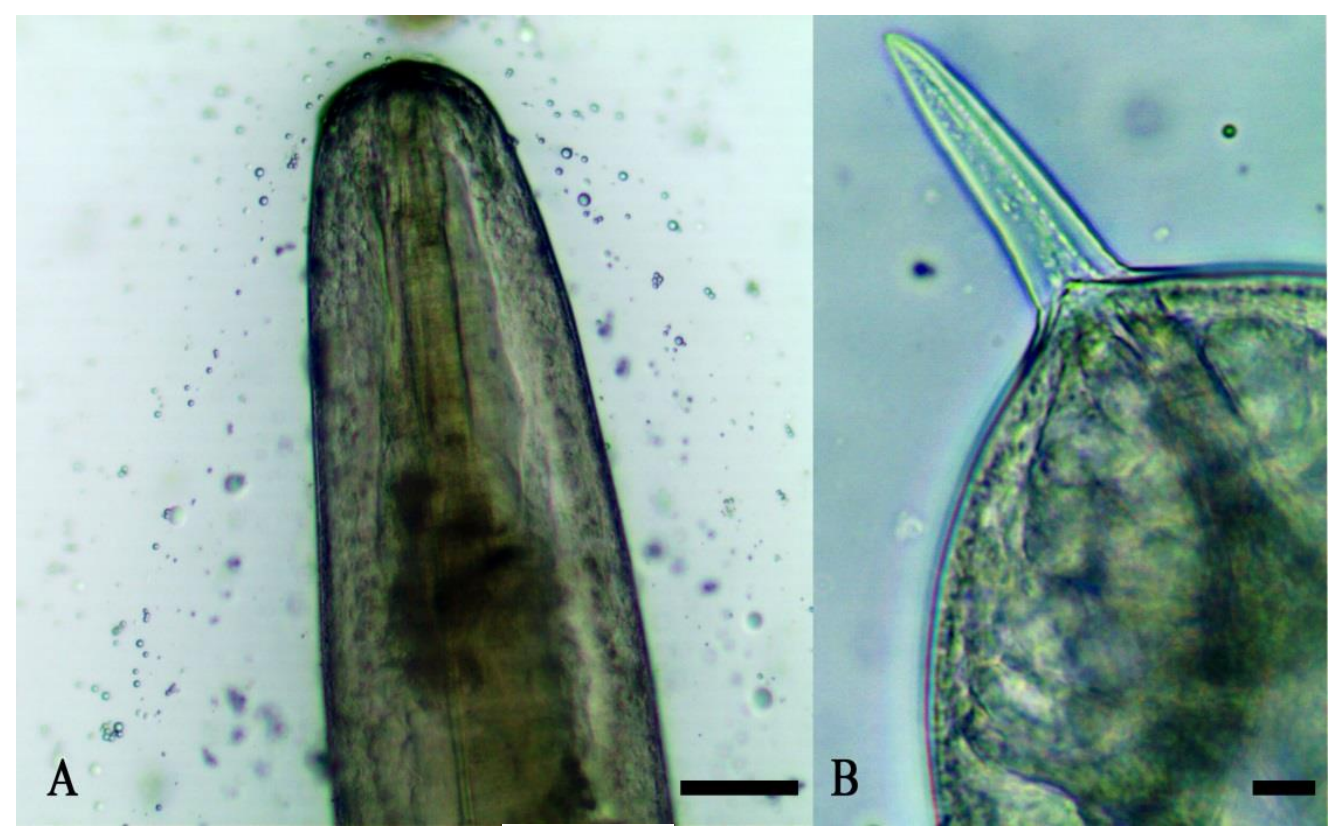

Figure 2. Mermithid parasite of $C$. livida. A: anterior end of juvenile mermithid (Bar: $100 \mu \mathrm{m})$; B: posterior end of juvenile mermithid. (Bars: $10 \mu \mathrm{m})$

\section{Discussion and conclusions}

Although Cantharidae members have great potential to use as predator beetle in biological control, there is no much knowledge concerning their natural pathogens and parasites. Researches to identify the natural enemies of this group are very limited. In most of the studies, while the fungal infections were common, a microsporidian and nematode infections were detected too $[10 ; 8 ; 9 ; 11]$. In 1980, Purrini [10] identified the new microsporidian pathogen, Pleistophora malthodes sp. n. from Malthodes fuscus Waltl. (Cantharidae) in Lower Saxony, Germany. This was the first and last study to determine the microsporidian pathogen from Cantharidae members. In another study conducted by Nielsen and Philipsen in 2003 [9], entomopathogenic nematodes Steinernema affine and Steinernema intermedium were determined from unknown Cantharis members (Cantharis spp.). This study is the only study that carried in Cantharidae family for nematode detection. In other studies that carried for determining the natural pathogen and parasites of Cantharidae members, usually fungi infections especially Entomophthorales infections were determined at the different species like Cantharis livida, Chauliognathus pensylvanicus, Chauliognathus marginatus and, etc. [8; 12; 11].

This study was conducted to determine natural entomopathogens of the C. livida in Turkey. During the examinations, one gregarine (Apicomplexa: Eugregarinorida), and one nematode (Nematoda: Mermithida) were determined for the first time. The isolated gregarine was a cephaline (septate) gregarine which composed of one protomerite and one deutomerite, separated by a septum.

Gregarines belonging to the phylum Apicomplexa are common parasites of invertebrates and low chordates and they are usually classified into three orders based on differences in life history: Archigregarinorida, Eugregarinorida and Neogregarinorida [17]. Especially Eugregarinorida is a common group that causes chronic infections at the insect taxa $[18 ; 19 ; 13 ; 20]$. Although gregarines are a common parasite in insect taxa, there is no record of infection in the Cantharidae family until this study. Only in Turkey, there are more than five gregarine infection records in different coleopteran members (Table 2). When compared to the current gregarine dimensionally with these records, current gregarine is smaller than the detected gregarine species by Yaman et. al [21] and Bekircan et al. [13]. And these records differentiating from the current gregarine according to the host species. They were isolated from Chrysomelidae members; Chrysolina fastuosa and Chrysolina herbacea, respectively. On the other hand, the current gregarine is larger than other records which were determined from Chrysomelidae members in Turkey (Table 2). Unfortunately, in this study, a species-level definition could not be made, since the life cycle was not completed and molecular identification could not be made. However, the gregarine parasite that was isolated from $C$. livida presented here, is the first gregarine in Cantharidae family. 
Table 2. The comparative characters of different gregarine records from coleopteran members

\begin{tabular}{|c|c|c|c|c|c|c|c|c|c|}
\hline 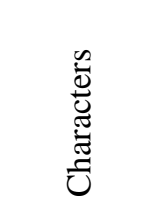 & 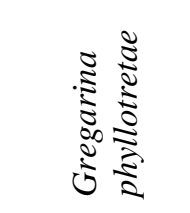 & 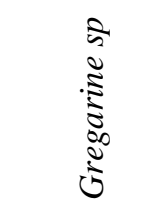 & 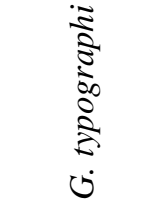 & 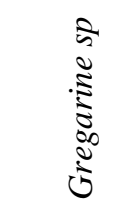 & 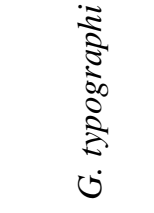 & $\begin{array}{c}5 \\
5 \\
0 \\
0 \\
0 \\
0 \\
0 \\
0\end{array}$ & $\begin{array}{c}0 \\
0 \\
0 \\
0 \\
0 \\
0 \\
0 \\
0 \\
0\end{array}$ & $\begin{array}{c}\text { की } \\
0 \\
0 \\
\vdots \\
0 \\
0 \\
0\end{array}$ & 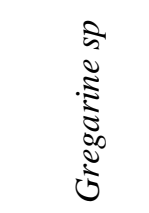 \\
\hline Host & $\begin{array}{l}\text { Phyllotreta } \\
\text { undulata, } \\
\text { Phyllotreta } \\
\text { atra }\end{array}$ & $\begin{array}{l}\text { Chaetocn } \\
\text { ema } \\
\text { tibialis }\end{array}$ & $\begin{array}{l}\text { Ips } \\
\text { sexdenta } \\
\text { tus }\end{array}$ & $\begin{array}{l}\text { Psylloid } \\
\text { es } \\
\text { cupreus }\end{array}$ & $\begin{array}{l}\text { Ips } \\
\text { typograp } \\
\text { hus }\end{array}$ & $\begin{array}{l}\text { Chrysol } \\
\text { ina } \\
\text { fastuosa }\end{array}$ & $\begin{array}{l}\text { Chrysol } \\
\text { ina } \\
\text { herbace } \\
\text { a }\end{array}$ & $\begin{array}{l}\text { Altica } \\
\text { hampei }\end{array}$ & $\begin{array}{l}\text { Canthari } \\
\text { s livida }\end{array}$ \\
\hline $\begin{array}{l}\text { Total } \\
\text { length } \\
(\mu \mathrm{m}) \\
\end{array}$ & 150 & $75-185$ & $80-275$ & $\begin{array}{l}177.2 \pm \\
44.4\end{array}$ & $90-155$ & $\begin{array}{l}462.8 \pm \\
103.7\end{array}$ & $\begin{array}{l}463.88 \\
\pm \\
113.96\end{array}$ & $\begin{array}{l}171 \pm \\
40.2\end{array}$ & $\begin{array}{l}240.4 \pm \\
29.0\end{array}$ \\
\hline $\begin{array}{l}\text { Protomer } \\
\text { ite }\end{array}$ & Conical & $\begin{array}{l}\text { spheruleli } \\
\text { ke to } \\
\text { knoblike } \\
\end{array}$ & $\begin{array}{l}\text { oval to } \\
\text { elongate }\end{array}$ & $\begin{array}{l}\text { Ellipsoi } \\
\text { dal to } \\
\text { ovoidal }\end{array}$ & $\begin{array}{l}\text { oval to } \\
\text { elongate } \\
\text { d }\end{array}$ & $\begin{array}{l}\text { Globula } \\
\text { r or oval }\end{array}$ & $\begin{array}{l}\text { Globula } \\
\text { r or oval }\end{array}$ & $\begin{array}{l}\text { Globular } \\
\text { or } \\
\text { conoidal } \\
\end{array}$ & $\begin{array}{l}\text { Globular } \\
\text { or oval }\end{array}$ \\
\hline $\begin{array}{l}\text { Deutome } \\
\text { rite }\end{array}$ & $\begin{array}{l}\text { hemicylindr } \\
\text { ical }\end{array}$ & & & $\begin{array}{l}\text { Ellipsoi } \\
\text { dal to } \\
\text { ovoidal }\end{array}$ & & & $\begin{array}{l}\text { Ellipsoi } \\
\text { dal }\end{array}$ & conoidal & $\begin{array}{l}\text { Cylindric } \\
\text { al to } \\
\text { conoidal }\end{array}$ \\
\hline $\begin{array}{l}\text { Gametoc } \\
\text { yst }\end{array}$ & $\begin{array}{l}\text { Ellipsoidal } \\
117 \text { x } 98\end{array}$ & & $\begin{array}{l}\text { Spherica } \\
1 \\
90 \times 100\end{array}$ & - & $\begin{array}{l}\text { Spherical } \\
77 \times 85\end{array}$ & $\begin{array}{l}\text { Ovodial } \\
314 x \\
266 \text { to } \\
427 x \\
372\end{array}$ & $\begin{array}{l}\text { Round } \\
298.78- \\
367.13 \\
\times \\
299.96- \\
311.64 \\
\end{array}$ & $\begin{array}{l}\text { Ovoidal } \\
202.9 \times 20 \\
0- \\
205.9 \times 20 \\
2.3\end{array}$ & $\begin{array}{l}\text { Ovoidal } \\
262.1 \times 27 \\
6.2\end{array}$ \\
\hline LP : TL & $1: 3-8$ & $3.3-9.8$ & $\begin{array}{l}1: 2.7- \\
5.3 \\
\end{array}$ & $\begin{array}{l}1: 3.9- \\
7.1\end{array}$ & $\begin{array}{l}1: 0.21- \\
0.32\end{array}$ & $\begin{array}{l}1: 3.9- \\
11.7\end{array}$ & $\begin{array}{l}1: 3.80- \\
7.31\end{array}$ & $1: 2.9-5.6$ & $1: 4.3-7.4$ \\
\hline WP:WD & $1: 1.1-1.7$ & $1.0-3.2$ & $\begin{array}{l}1: 1.1- \\
1.3 \\
\end{array}$ & $\begin{array}{l}1: 1.1- \\
2.3\end{array}$ & $\begin{array}{l}1: 0.74- \\
1.08\end{array}$ & $\begin{array}{l}1: 0.9- \\
1.9\end{array}$ & $\begin{array}{l}1: 1.16- \\
3.13\end{array}$ & $1: 0.6-2.5$ & 1: $1.1-1.8$ \\
\hline $\begin{array}{l}\text { Referenc } \\
\text { e }\end{array}$ & [30] & [31] & [32] & [33] & [34] & [21] & [13] & [20] & $\begin{array}{l}\text { In the } \\
\text { present } \\
\text { study }\end{array}$ \\
\hline
\end{tabular}

TL; total length, LP; length of protomerite, WP; width of protomerite, WD; width of deutomerite, LP:TL; ratio of the length of protomerite to total length, WP:WD; ratio of the width of protomerite to the width of deutomerite.

Another parasite determined in this study was a nematode. With a wire-like body shape and smooth cuticle with layers of spiral fibres, this nematode was a mermithid species. The taxonomy of the Mermithidae has been complicated due to insufficient sample collection as well as very limited morphological characteristics. Even the beststudied species in this taxon, Romanomermis culicivorax, has an unclear taxonomic status [22]. Similarly, in this study only juvenile stages of the current mermithid were determined, other life cycle stages (adult, egg and etc.) and related taxonomic characters required for species identification could not be determined. However, the relevant literature and the examined juvenile morphological features prove that the detected nematode shows great similarity with the genus Hexamermis $[16 ; 23 ; 24]$. This genus is characterized with taxonomic parameters such as the medium-sized, white color; postparasitic juvenile and adult cuticles with cross fibers; terminal mouth; postparasitic juvenile with tail appendage and etc. [25; 26]. The current mermithid determined in this study had a medium-sized $(270-281 \mu \mathrm{m}$ in width and 68.6-79.98 $\mathrm{mm}$ in length), white color, terminal mouth and tail appendage $(51.8 \mu \mathrm{m})$.

Similar to gregarine infections, mermithid infections in coleopteran members are frequent in Turkey. In 2006, Mennan and Ertürk [27] determined mermithid infection from Leptinotarsa decemlineata Say, 1824 (Coleoptera: Chrysomelidae) and they measured this juvenile form as a $0.2-0.3 \mathrm{~mm}$ width and $150 \mathrm{~mm}$ length. In this study, the researchers reported that the anterior end of the juvenile form was blunt while the posterior end had a distinct short, finger-like tail appendage about $40 \mu \mathrm{m}(38-48 \mu \mathrm{m})$. In another study, conducted by [28], a juvenile mermithid was determined from Phyllotreta undulata Kutschera, 1860 (Coleoptera: Chrysomelidae) with 152-162 $\mu \mathrm{m}$ width and 10.6$12.2 \mathrm{~mm}$ length. While this mermithid had a blunt anterior end, the posterior end had an appendage tail of about $52 \mu \mathrm{m}$. In 2011, Yaman et al. [21] reported another mermithid infection from Chrysolina fastuosa Scopoli, 1763 (Coleoptera: Chrysomelidae). They measured this mermithid $94 \mathrm{~mm}$ in length and $278.5-317.5 \mu \mathrm{m}$ in width. Finally, in 2019 Bekircan and friends [29] determined another mermithid from Agelastica alni L. 1758 (Coleoptera: Chrysomelidae) and it was measured $0.2-0.4 \mathrm{~mm}$ in width; $75-81 \mathrm{~mm}$ in length in this study. 
In conclusion, this study was conducted for the determining the natural pathogen and parasite of the Cantharis livida L. 1758 (Coleoptera: Cantharidae) in Turkey. And one cephaline (septate) gregarine and mermithid infections were reported from the Cantharidae family for the first time with this study.

\section{References}

[1] Schuber, J., M., Monteiro, L., B., Almeida, L., M., \& Zawadneak, M., A., C. (2012). Natural enemies associated to aphids in peach orchards in Araucária, Paraná, Brazil. Brazilian Journal of Biology, 72, 847-852.

[2] Yıldırım, E., Kopetz, A., \& Bulak, Y. (2011). Contribution to the knowledge of the Cantharidae (Coleoptera) fauna of Turkey. Linzer Biologische Beiträge, 43(2), 1641-1646.

[3] Gümüş, A., \& Avc1, M. (2015). Poplar pest insects and their predators in Isparta province. Turkish Journal of Forestry, 16(2), 111-129.

[4] Kaya, H., K., \& Vega, F., E. (2012). Scope and basic principles of insect pathology. In H. K. Kaya \& F. E. Vega (Eds.), Insect Pathology (pp. 1-12). London: Elsevier Inc.

[5] Boucias, D., G., \& Pendland, J., C. (1998). Principles of Insect Pathology. Boston: Kluwer Academic.

[6] Cantwell, G., E. (Ed.). (1974). Insect Diseases, Vols. 1 and 2. New York: Marcel Dekker.

[7] Tanada, Y., \& Kaya, H., K. (1993). Insect Pathology. San Diego: Academic Press.

[8] Eilenberg, J., Bresciani, J., \& Martin, J. (1987). Entomophthora species with E. muscae-like primary spores on two new insect orders, Coleoptera and Hymenoptera. Nordic Journal of Botany, 7, 577-584.

[9] Nielsen, O., \& Philipsen, H. (2003). Danish surveys on insects naturally infected with entomopathogenic nematodes. Insect Pathogens and Insect Parasitic Nematodes IOBC wprs Bulletin, 26 (1), 131-136.

[10] Purrini, V., K. (1980). Pleistophora malthodes sp. n. (Microsporidia, Protozoa) eine neue Mikrosporidie aus Malthodes fuscus Waltl. (Cantharidae, Coleoptera). Anzeiger für Schädlingskunde, Pflanzenschutz, Umweltschutz, 53, 87-88.

[11] Steinkraus, D., C., Hajek, A., E., \& Liebherr, J., K. (2017). Zombie soldier beetles: Epizootics in the goldenrod soldier beetle, Chauliognathus pensylvanicus (Coleoptera: Cantharidae) caused by Eryniopsis lampyridarum (Entomophthoromycotina: Entomophthoraceae). Journal of Invertebrate Pathology, 148, 51-59.

[12] Wheeler, A., G. (1988). Violent deaths" of soldier beetles (Coleoptera: Cantharidae) revisited: new records of the fungal pathogen Eryniopsis lampyridarum (Zygomycetes: Entomophthoraceae). The Coleopterists Bulletin, 42(3), 233-236.

[13] Bekircan, Ç., Tokarev, Y., Tosun, O., \& Baki, H. (2016). Detection of Neogregarine and Eugregarine Apicomplexa Infections from Chrysolina herbacea (Duftschmid 1825) (Coleoptera: Chrysomelidae) in Turkey. Turkish Journal of Life Sciences, 1(2), 59-64.

[14] Bekircan, Ç., Baki, H., \& Tosun, O. (2018). The Distribution of Aranciocystis muskarensis (Neogregarinida: Ophryocystidae) in Populations of Anisoplia segetum Herbst (Coleoptera: Scarabaeidae) in Turkey and Its Relationship with Climatic Factors. Turkish Journal of Agricultural and Natural Sciences, 5(2), 146-152.

[15] Lipa, J., J. (1967). Studies on Gregarines (Gregarinomorpha) of Arthropods in Poland. Acta Protozoologica, 5, 97-179.

[16] Poinar, G., O. (1988). Nematode parasites of Chrysomelidae. In E. Petitpierre, T. H. Hsiao, \& P. H. Jolivet (Eds.), Biology of Chrysomelidae (pp. 433- 448), Boston: Kluwer Academic Publishers.

[17] Perkins, F., O., Barta, J., R., Clopton, R., E., Pierce, M., A., \& Upton, S., J. (2002). Phylum Apicomplexa Levine, 1970. In: J. J. Lee, G. F. Leedale, \& P. Bradbury (Eds.), An Illustrated Guide to the Protozoa (second ed., vol. 1.) Lawrence, KS, USA, Society of Protozoologists.

[18] Théodoridés, J. (1988). Gregarines of Chrysomelidae. In E. Petitpierre, T. H. Hsiao, \& P. H. Jolivet (Eda.), Biology of Chrysomelidae, Boston: Kluwer Academic Publishers, 417-431.

[19] Tosun, O., Yaman, M., \& Aydin, Ç. (2008). Parasites of Phyllotreta atra (Fabricius, 1775) (Coleoptera: Chrysomelidae) in Trabzon. Turkish Journal of Parasitology, 32(2), 153-157.

[20] Yıldırım, H., Tosun, O., \& Bekircan, Ç. (2019). The First Record af A Gregarine Pathogen from Altica hampei (Allard, 1867) (Coleoptera: Chrysomelidae). Kahramanmaraş Sütçü İmam Üniversitesi Tarım ve Doğa Dergisi, 22(5), 799-805.

[21] Yaman, M., Tosun, O., Lipa, J., J., \& Aslan, İ. (2011). First Records of A Gregarine Pathogen and A Mermithid Parasite from Chrysolina fastuosa (Scopoli 1763) (Coleoptera: Hrysomelidae). North-Western Journal of Zoology, 7(1), 105-111 
[22] Petersen, J., J. (1985). Nematodes as biological control agents: Part 1. Mermithidae, In J. R. Baker \& R. Muller (Eds). Advances in Parasitology (pp 307-344). London: Academic Press.

[23] Kaiser, H. (1991). Terrestrial and semiterretrial Mermithidae. In W. R. Nickle, M. Dekker (Eds.), Manual of Agricultural Nematology (pp. 899-965). New York.

[24] Drea, U., Gruber, F., Fuester, R., W., Mercadier, G., \& Hoyer, H. (1997). Observations on Hexamermis albicans (Nematoda: Mermithidae) recovered from Lymantria dispar and Stilpnotia salicis (Lep: Lymantriidae) in West Germany and Austria. Entomophaga 22, 141-146.

[25] Steiner, G. (1924). Beitrage zur Kenntnis der Mermithidae. 2 Teil. Mermithiden aus Paraguay in der Sammlung des Zoology. Museums zu Berlin. Zentralblatt fuer akteriologie Parasitenkunde Infektionskrankheiten. 62, 90 110 .

[26] Mazza, G., Paoli, F., Strangi, A., Torrini, G., Marianelli, L., Peverieri, G. S., ... Poinar, G. O. (2017). Hexamermis popilliae n. sp. (Nematoda: Mermithidae) parasitizing the Japanese beetle Popillia japonica Newman (Coleoptera: Scarabaeidae) in Italy. Systematic Parasitology, 94(8), 915-926. doi:10.1007/s11230-0179746-0

[27] Mennan, S., \& Ertürk, Ö. (2006). First record of parasitism of a Mermithidae (Nematoda) on Leptinotersa decemlineata (Col: Chrysomelidae) in Turkey. Pakistan Journal of Nematology. 24, 39-43.

[28] Yaman, M., Tosun, O., \& Aydın, Ç. (2009). Occurrence of The Pathogens and Parasites of Phyllotreta undulata (Coleoptrea: Chrysomelidae) İn Turkey. Turkish Journal of Zoology, 33, 139-146.

[29] Bekircan, Ç., Tosun, O., \& Yıldırım, H., (2019 Aralık 27-29). Kızılă̆aç Yaprak Böceği Agelastica alni (Coleoptera: Chrysomelidae) de Türkiye İçin İlk Mermitid (Mermithida: Mermithidae) Enfeksiyonu Kaydl, 2. Uluslararası 19 Mayıs Yenilikçi Bilimsel Yaklaşımlar Kongresi, Samsun Türkiye

[30] Yaman, M. (2002). Gregarina phyllotretae (Hoshide, 1953), a Protozoan Parasite of the Flea Beetles, Phyllotreta undulata and P. atra (Coleoptera: Chrysomelidae) in Turkey. Applied Entomology and Zoology, 37(4), 649-53.

[31] Yaman, M. (2004). A Newly Recorded Gregarine Parasite of Chaetocnema tibialis (Coleoptera: Chrysomelidae) from Turkey. Turkish Journal of Zoology, 28(1), 95-96.

[32] Yaman, M. (2007). Gregarina typographi Fuchs, a gregarine pathogen of the six-toothed pine bark beetle, Ips sexdentatus (Boerner) (Coleoptera: Curculionidae, Scolytinae) in Turkey. Turkish Journal of Zoology, 31, 359363.

[33] Yaman, M., Tosun, O., \& Aslan, İ. (2008). On The Occurrence of A Gregarine Parasite from Psylloides cupreus (Koch 1803) (Coleoptera: Chrysomelidae) of Turkey. North-Western Journal of Zoology, 4(1), 167-172.

[34] Yaman, M., \& Baki, H. (2010). The First Record of Gregarina typographi Fuchs. (Protista: Apicomplexa: Gregarinidae) from the European Spruce Bark Beetle, Ips typographus (Linnaeus) (Coleoptera: Curculionidae:Scoltinae) in Turkey. Turkish journal of Parasitology, 34 (4), 179-82. 